\title{
EDITORIAL
}

\section{International Dispute Settlement - from Practice to Legal Discipline}

\author{
ERIC DE BRABANDERE*
}

The area of international dispute settlement is relatively new in the international legal discipline as an academic enterprise. In this editorial, which is based on my inaugural address, ${ }^{\mathrm{I}} \mathrm{I}$ intend to trace the emergence of international dispute settlement as a legal discipline. The main thrust of my argument is that international dispute settlement has long not been considered as a discipline of its own - within or outside the international legal discipline - nor given space as a separate field of research. The reasons for this are manifold, but one reason is in my view central: international dispute settlement was long considered more practice than discipline, a practice that occasionally deserved some academic attention, but that was not considered as an area of research in its own right within the broader field of international law. This may be traced back to the limited practice and the historical view in international legal discourse of international dispute settlement as something that is concerned with the application of the law, and hence as something aspirational in nature. International dispute settlement was more about the law than law in itself.

I argue that this has however changed, not only because the perception of dispute settlement has changed, but also because - in contrast to the pre-Cold War period the practice has substantially increased over the past decade.

\section{THE POSITION OF INTERNATIONAL DISPUTE SETTLEMENT IN THE STUDY OF INTERNATIONAL LAW}

\section{I.I. The aspirational nature of international dispute settlement}

International dispute settlement has long been perceived as something more akin to a diplomatic and political endeavour, being aspirational in character. The aspirational nature of international dispute settlement is visible from the excessive focus in the history of international dispute settlement, both in politics and scholarship, on the exclusive question whether there is a need or not for a compulsory method to settle disputes. Supporters considered that there was such a need, inspired by a sense of justice for those states whose rights had been breached, by the idea that dispute

Professor of International Dispute Settlement Law and Director of the Grotius Centre for International Legal Studies; Attorney (Ghent, Belgium) [e.c.p.d.c.de.brabandere@law.leidenuniv.nl].

For a more expanded text, see www.universiteitleiden.nl/binaries/content/assets/algemeen/oraties/oratie-debrabandere.pdf. 
settlement was necessary to avoid recourse to war, ${ }^{2}$ or by the less philanthropic idea that dispute settlement, or more broadly enforcement, was necessary in order for international law to be considered law. ${ }^{3}$

From the I87os onwards, proposals for the establishment of some system to arbitrate international disputes were becoming common, in line with the generally favourable attitude towards international law and its role in international society. ${ }^{4}$ This resulted in a formalization of international arbitration which found its culmination in the creation of the Permanent Court of Arbitration (PCA) during the first Hague Peace Conference of I899. What is important is that international arbitration was seen, and still is seen today, as the method - par excellence - to avoid recourse to war and as the means to achieve respect for international law or ensure implementation of international law.

During the first Hague Peace Conference of I899 during which the PCA was created, for the first time in history something akin to a permanent international arbitral tribunal was created. But there was no compulsory submission of disputes to the PCA, and the PCA, despite its name, was neither a court nor a permanent tribunal, leading to quite some disillusionment amongst those who had strongly militated in favour of a mandatory recourse to arbitration to avoid recourse to war. As Tobias Asser explained: 'Instead of a permanent court, the Convention of I 899 gave but the phantom of a court, an impalpable spectre, or to be more precise yet, it gave us a recorder with a list'. ${ }^{5}$ When the second Hague Peace Conference was convened in I907, disappointment made way for some renewed enthusiasm for the idea of a permanent tribunal with compulsory jurisdiction, but again the dichotomy between the political preference for a mandatory system of dispute settlement was at its apex. The Russian delegate, Mr. de Martens asked all delegates to join him in achieving 'progress' and supporting the 'great ideal ... of arbitration'. ${ }^{6}$ This statement, while encouraging, was in fact more wishful thinking, and the outcome of the Second Hague Peace Conference showed that the Russian delegate had not managed to convince his fellow delegates to create a truly compulsory court of arbitration. The Belgian delegate, Mr. Beernaert, for one, opposed the creation of a compulsory court of arbitration on the pragmatic consideration that such a project, if adopted, would simply not gather the necessary support of the states and thus remained a 'dream'.

These and other fine examples of advocacy are probably inherent in any international negotiation, but the important point here is that that 'higher' aspirational

See M.E. O’Connell, 'Arbitration and Avoidance of War: The Ninetheenth-Centruy American Vision', in C. P.R. Romano (ed.) The Sword and the Scales: The United States and International Courts and Tribunals (2009), 30-45.

3 See the discussion in H.L.A. Hart, The Concept of Law (I997), Ch. X. See also for a discussion S. Besson, 'Legal Philosophical Issues of International Adjudication. Getting over the Amour Impossible between International Law and Adjudication', in C.P.R. Romano, K.J. Alter and Y. Shany (eds.), The Oxford Handbook of International Adjudication (2013), 4I5.

4 W.G. Grewe, The Epochs of International Law (2000), 5 I 7.

T.M.C. Asser, Speech, in Scott, The Proceedings of the Hague Peace Conference, II, at 232, 235.

Ibid., at 325-8.

Ibid., at $332-6$. 
goal or ideology dominated international attention and discussion - especially in scholarship, as I will explain in the next section. ${ }^{8}$

And these questions continued to gather attention in the twentieth century, although the context in which the discussion took place was slightly different. After the creation of the Permanent Court of International Justice(PCI) in I920, discussion on whether or not an institution with compulsory jurisdiction needed to be created became of less relevance since many believers had achieved what they were longing for - a standing court worthy of that name. Its permanent and especially its standing character was considered a major achievement. The PCIJ, much as the PCA, was seen as part of the 'system of war prevention', 9 but there was one important difference with the discussions in the context of the PCA: the PCIJ was established in the context of a strong belief not only in a form of compulsory settlement of disputes to avoid 'war', but also in an institutionalization to bring about peace and development, as exemplified by the creation of the League of Nations. ${ }^{\text {Io }}$

After the Second World War, the United Nations and its principal judicial organ, the International Court of Justice (ICJ), were created. The ICJ, similar to the PCIJ, was considered important to provide a system of enforcement against those states which would breach the law and to that end high hopes were again put in this ambitious endeavor by the negotiators of the Statute of the ICJ and the United Nations Charter. It is not a coincidence that the obligation to settle disputes in a peaceful way is provided in Article 2 paragraph 3 of the UN Charter, just before the prohibition on the use of force, mentioned in Article 2 paragraph 4 of the UN Charter. The failures of the PCIJ and the League of Nations were considered to have been addressed with these new institutions, ${ }^{\mathrm{II}}$ although many features of the PCIJ had simply been taken over in the Statute of the ICJ.

The basically non-legal academic debate between the 'believers' and 'nonbelievers' has obstructed the move towards treating international dispute settlement as a question that relates to law rather than political preference, and as explained already, much of the original attention devoted to arbitration and dispute settlement orbited around the specific question of the desirability of compulsory dispute settlement. ${ }^{\mathrm{I2}}$ This is most visible through various publications on international arbitration which appeared during the so-called 'Peace Movement' between the I870s

8 See also M. Koskenniemi, ‘The Ideology Of International Adjudication' (7 September 2007), available at www.helsinki.fi/eci/Publications/Koskenniemi/MKHague\%201907-puheversioo7a.pdf.

9 Grewe, supra note 4, at 6I6.

ro See L. Tosi, 'The League of Nations: An international relations perspective', (2017) 22 Uniform Law Review I $48-57$.

II A notable criticism concerned the role of the League of Nations Council, which, compared to the PCIJ, was considered - by Hans Kelsen amongst others - to be too much at the center of the League of Nations system. See for a discussion A. von Bogdandy and I. Venzke, In Whose Name? A Public Law Theory of International Adjudication (2014), 55-6.

I2 See for instance R. Finlay, 'International Arbitration', (1904) I79 The North American Review 659-70; P.S. Reinsch, 'The Concept of Legality in International Arbitration', (I9I I) 5 American Journal of International Law 604-I4; and H. Wehberg, 'Restrictive Clauses in International Arbitration Treaties', (I9I3) 7 American Journal of International Law $30 \mathrm{I}-\mathrm{I} 4$. 
and the early nineteenth century, ${ }^{\mathrm{I} 3}$ because that was the main question diplomats and negotiators were in fact discussing.

\section{I.2. Limited practice and limited institutions}

Until recently, the extent of the practice of international courts and tribunals and arbitration has remained all in all relatively limited, with the exception of certain peaks of activity, which were limited in time and also limited to one particular institution or method of dispute settlement, thus hindering any transformation of that stand-alone practice into something broader and more systemic. Dispute settlement mechanisms resulting in a binding outcome remained confined to two institutions only: the PCIJ and its successor - the ICJ - and international arbitration.

As far as arbitration is concerned, arbitration in general and the PCA initially resulted in an impressive outcome. Some 330 arbitrations were conducted between I794 and I9I9, 242 of which took place between I870 and I9I9. ${ }^{\text {I4 }}$ After the creation of the PCIJ, and then the ICJ, the PCA almost fell into oblivion after the Second World War and until the end of the I 990s, with little to no international arbitrations conducted under its auspices. More generally, interstate arbitrations then were very limited. ${ }^{15}$

As far as judicial settlement is concerned, one can only say that the PCIJ was a relatively successful, yet short-lived experiment. Initially, many disputes were settled by the PCIJ, which delivered decisions in 3 I contentious cases between states and 27 advisory opinions, between 1922 and I940. ${ }^{16}$ But its activities were in steep decline in the I930s, the Court was unable to sit between I94 I and I944-during the Second World War - and it ceased work in I 945. The successes the PCIJ had achieved in this short period of time were not sufficient to create something akin to a dispute settlement system, and international scholarly attention to the PCIJ rapidly faded away as the PCIJ's activities declined.

And until the end of the I970s, the ICJ rendered only 39 judgements and I6 advisory opinions, related to disputes and questions which have been described as of 'minor importance'. ${ }^{\text {I7 }}$ Political settlement dominated judicial settlement. ${ }^{\text {I }}$

This 'dispute settlement inactivity' can be traced back to the fact that the sovereignty and sovereign equality of states still requires the explicit consent of the states parties to a dispute to have this dispute settled through arbitration or international adjudication, and to the paralleled rise in the post-Second World War period of international legal realism emphasizing the distinction between confined legal-technical disputes and political tensions or conflicts which were not capable of being or should not be settled through legal dispute settlement mechanisms such

\footnotetext{
I3 See M.E. O'Connell and L. Vanderzee, 'The History of International Adjudication', in C.P.R. Romano, K.J. Alter and Y. Shany (eds.), The Oxford Handbook of International Adjudication (2013), 40-6I; and O'Connell, supra note 2, at 37 .

I4 A.M. Stuyt, Survey of International Arbitrations I794- I939 (I939; reprinted by Springer, 20I4).

I5 See A.M. Stuyt, Survey of International Arbitrations I 794-I 989 (I 990).

i6 See www.icj-cij.org/en/pcij.

I7 I. Seidl-Hohenveldern, Völkerrecht (I980), 34I.

I8 Grewe, supra note 4, at 665.
} 
as courts and tribunals. ${ }^{19}$ Despite opposition to legal realism and to that specific question from several scholars, notably Hersch Lauterpacht, ${ }^{20}$ legal realism found its way to governments and domestic policies for several decades. ${ }^{2 \mathrm{I}}$

Until recently, international dispute settlement thus suffered from a lack of institutionalization - which I take here in its broadest sense as referring to the establishment and recognition of the concept of dispute settlement within the international society. The limited practice of courts and tribunals has always been the produce of a single institutional setting - the PCA, the PCIJ, and then the ICJ - with occasional surges in arbitration. There was thus a form of institutionalization, which of course attracted the necessary attention and comments, but this institutionalization was limited mainly to that single mechanism to settle disputes - international dispute settlement as such was not institutionalized or considered to be more than the limited practice of the PCIJ, the ICJ or of inter-state arbitral tribunals. And institutionalization is important since, amongst others, it implies the transformation of a certain practice from something merely practical or aspirational into a legal scientific concern. Ad hocism is not a catalyst for recognition as a legal discipline it is only when certain institutions are created that an area of practice becomes of interest to the legal academic community.

Moreover, the limited practice in international law has had as main consequence that the relevance of international arbitration and international adjudication for international law was simply limited.

\section{INTERNATIONAL DISPUTE SETTLEMENT AS A PRACTICE}

Related to my two previous points, international dispute settlement has since long been regarded as a practice, and not something worthy of study in an independent legal discipline. This view of the field is perhaps the logical consequence of my previous points that international dispute settlement and specifically international arbitration was considered as a mere way to diplomatically settle conflicts between two or more states, or between states and private parties at a later stage, a means to apply the law or to ensure respect for the law, rather than law itself.

This is, of course, inherent in the fact that we are dealing here with the settlement of international disputes. Settling disputes is intrinsically practical in nature and is in its purest form indeed nothing more than applying the law rather than law in itself. For long, the translation of the idea that international law is about applying the law rather than anything else, can be found in the general view that acting as arbitrator is not a profession in and of itself - one is asked to settle a dispute as a (remunerated) service to society. ${ }^{22}$

In international law, the same is without doubt also - and perhaps even more true. Because of the predominance of the use of arbitration to settle international

See H. Morgenthau, Die internationale Rechtspflege. Ihr Wesen und ihre Grenzen (1929), 60.

H. Lauterpacht, The Function of Law in the International Community (I933; reprinted in 200I), I6I ff.

M. Koskenniemi, The Gentle Civilizer of Nations. The Rise and Fall of International Law I870-I960 (200I), 4I $3 \mathrm{ff}$.

T. Clay, 'Qui sont les arbitres internationaux - Approche sociologique', in J. Rosell (ed.), Les arbitres interna-

tionaux: Colloque du 4 février (2005), $3 \mathrm{I}$. 
law disputes, the vast majority of international disputes were settled by individuals who did this alongside any other function they had - they were temporarily called upon to exercise an arbitral function as a service to the international society of states. Especially at a time when international courts and tribunals did not exist, or were limited in number, this was inevitable. But even thereafter, this practice persisted, probably for the same reason that arbitrators in commercial disputes are not professional adjudicators.

That perspective of the arbitral function, in international law, as a service to society is of course characteristic of the (international) legal system. My main point here, however, is that, until recently, this has resulted in a perception of international dispute settlement, and especially arbitration, as a field of practice in essence.

Even if such procedures were in and of themselves interesting from a legal scientific perspective, the idea that dispute settlement merely is about applying the law resulted in the fact that most attention was paid to compiling the practice rather that analyzing it. Also, the writings on arbitration were often confined to the sphere of mixed arbitrations between states and foreign companies and commercial arbitration, and were focusing also more on the outcome of arbitration or compiling that practice - not the least also because of the general distrust of practitioners towards non-practising academics. ${ }^{23}$

In addition, there was initially much focus on certain practicalities or institutionoriented questions relating to dispute settlement and arbitration, or on how a specific court or tribunal functioned. ${ }^{24}$ Also, because of the practice-oriented approach to the field, academic attention and publications in the field of international dispute settlement and most notably in international arbitration, was mostly the work of practitioners and academics/practitioners who in most cases limited their research and writings to practical problems in the arbitration they were facing in their practice. $^{25}$

But as disputes were submitted to the existing mechanisms, academic attention increased and moved beyond the question whether one should settle disputes to the output of dispute settlement processes. The main works dealing with international courts and tribunals, historically, focused on how courts and tribunals applied the law and whether and how decisions rendered by these courts and tribunals contributed to the development or clarification of the law. ${ }^{26}$

To sum up, international dispute settlement as such was not really touched upon

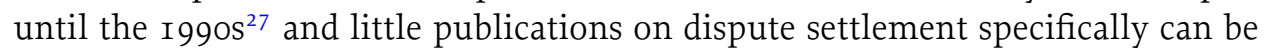
found between I 950 and I 990 . This is not to say that international dispute settlement

23 T. Schultz, 'Editorial: Arbitration as an iPhone, or Why Conduct Academic Research in Arbitration', (20I I) 2 Journal of International Dispute Settlement 279, at 28I.

24 See, for instance, A. Pandelli Fachiri, The Permanent Court of International Justice: Its constitution, procedure and work (I 925); and M.O. Hudson, The Permanent Court of International Justice: A treatise (I 934).

25 See S. Brekoulakis, 'International Arbitration Scholarship and the Concept of Arbitration Law', (2013) 36 Fordham International Law Journal 745, at 763 ff; and Schultz, supra note 23, at 280.

26 See, e.g., H. Lauterpacht, The Role of Law in the International Community(I933); G. Schwarzenberger, International Law, as applied by international courts and tribunals (I945); and B. Cheng, General Principles of Law as Applied by International Courts and Tribunals (I953).

27 Besson, supra note 3, at 4I5. 
remained completely unnoticed in scholarship. In addition to the exceptions mentioned above, the vast majority of international law handbooks or textbooks in that period did pay attention to the ways in which international disputes were settled. But these works were in view of the limited institutions, geared towards compiling the practice of a specific institution, such as the ICJ, and towards explaining the working procedures of the specific institutions. Thus, here again, the analysis was more than often confined to the output of dispute settlement, rather than dispute settlement as such.

\section{HAS IT CHANGED, AND WHY HAS IT CHANGED?}

Academic research on international dispute settlement has increased rapidly over the past two decades. Especially from a research perspective, attention has shifted from looking only to the output of dispute settlement or a specific institution, to also examining the law of international dispute settlement, evidenced by the inclusion of dispute settlement in the profiles of international law journals, such as the Leiden Journal of International $\mathrm{Law}^{28}$ and even specific law journals dedicated to the field, such as the Journal of International Dispute Settlement.

\section{I. An increase in the practice of international dispute settlement}

The first and most obvious reason relates to the fact that international arbitration and international courts and tribunals cannot nowadays - quantitatively - be marginalized in view of the large number of disputes settled through such means. The ICJ has since a decade (almost) never been as active as it is. The International Tribunal for the Law of the Sea has decided some 25 disputes since it heard its first case in I997, the World Trade Organization Dispute Settlement System has decided over 500 disputes since I 995; and the total number of arbitrations in which the PCA acted as a registry amounted to $\mathrm{I} 48$ in $20 \mathrm{I} 6$, of which 40 were initiated in that year. ${ }^{29}$ The International Centre for Settlement of Investment Disputes (ICSID), the most used forum for the settlement of investment disputes, has similarly - as is widely known - registered a record number of cases over the past decade ${ }^{30}$ and according to UNCTAD, a total of 767 known investment arbitrations based on international investment treaties have been concluded or are pending. ${ }^{3 \mathrm{I}}$

With the increase of the relevance of international dispute settlement and arbitration, comes an increase in public relevance and academic attention to the field. Questions such as how the courts and tribunals function, who the arbitrators and judges that decide cases are and which rules of independence and impartiality apply to them, how consent is expressed and established, why a certain method of dispute

\footnotetext{
28 See E. De Brabandere and I. Venzke, 'The Leiden Journal of International Law at 30', (2017) 30 Leiden Journal of International Law I-4.

29 PermanentCourt of Arbitration(PCA)(20I6), I I $6^{\text {th }}$ Annual Report, 20I6, available at pca-cpa.org/wp-content/ uploads/sites/I75/2017/03/ONLINE-PCA-Annual-Report-2016-28.02.2017.pdf.

30 ICSID Caseload-Statistics(Issue 20I 7-2), available aticsid.worldbank.org/en/Documents/resources/ICSID\% 20Web\%20Stats\%202017-2\%20(English)\%20Final.pdf.

3 I See investmentpolicyhub.unctad.org/ISDS.
} 
settlement is more effective than another or preferred, whether and under which conditions a court or arbitral tribunal can order provision measures, or what the authority of international courts and tribunals is ${ }^{32}$-some of the backbone questions of international dispute settlement - have now become relevant because such courts and tribunals are publicly and academically visible and meaningful as a subject of enquiry, which in turn rests in large parts on a quantitative increase of their output.

\subsection{The institutionalization of dispute settlement}

Recent decades have seen a clear increase in the number of legal dispute settlement mechanisms, referred to as 'the proliferation of judicial institutions'. The increase in the practice and of dispute settlement institutions as such, should be coupled to an increased acceptance by states of the jurisdiction of courts and tribunals, and of arbitral tribunals. To become a member of the World Trade Organization implies the acceptance of the compulsory competence of the dispute settlement system provided for in the Marrakech Agreement. Parties to the Law of the Sea Convention likewise are bound - with certain exceptions - to choose submission of disputes that arise under that convention to either the Law of the Sea Tribunal, the ICI, or to arbitration, the Law of the Sea Tribunal having moreover two instances of compulsory jurisdiction. In the area of investor-state arbitration, it is finally noticeable that the vast majority of the 3,000 or so investment treaties provide direct access for foreign investors to international arbitration. As a consequence, as Samantha Besson has put it 'current international law can no longer be understood without its judicial dimension', 33 to which I would add the arbitral dimension.

The main explanation for the increased acceptance by states of the jurisdiction of courts and tribunals, and the creation of mechanisms to that effect, is the selfinterested or self-centred nature of states - states accept the competence of a court or tribunal in advance only to the extent that it serves their interest. This has always been the case and has not changed, with the exception of certain areas of international law which have grown substantially in importance in the past decades. A first example is dispute settlement at the World Trade Organization where the downsides of not settling disputes that would impact the international trade outweigh clinging to the principle of sovereign independence and the sporadic ad hoc acceptance of the jurisdiction of a court to settle that dispute. The same holds true in respect of investor-state arbitration where the signature of an investment treaty with an arbitration clause giving foreign investors direct access to arbitration is partly driven by the consideration that doing so is in their interest in order to stimulate foreign investment, although it is beyond doubt that many other factors have also contributed to this practice.

Of course, state interests continue to play a role in this debate. While the relinquishment - legally speaking - of the old debate on the distinction between

\footnotetext{
32 A. von Bogdandy and I. Venzke, 'In Whose Name? An Investigation of International Courts' Public Authority and Its Democratic Justification', (2OI 2) 23 European Journal of International Law 7-4I.

33 Besson, supra note 3, at 4I5.
} 
political and legal disputes recently came up before the ICJ, ${ }^{34}$ the limited number of acceptances of the compulsory jurisdiction of the ICJ can still be explained by the fact that states are unwilling to relinquish control over certain of their interests, especially those which were previously captured by the category of 'non-justiciable disputes'. To keep a certain liberty in deciding whether or not to accept the Court's jurisdiction on an ad hoc basis is also why the number of states which have accepted the compulsory jurisdiction of the ICJ has not grown substantially over the past decades.

\subsection{Is international dispute settlement still a practice?}

Of course, international dispute settlement still is a practice. But not in the same sense as it was perceived before. For sure, arbitrators and judges still are appointed because they are considered best suited to settle the dispute-and settling the dispute still is their main task. But the increase in the number of courts and tribunals has nonetheless given rise to research into that practice.

More generally, the increased academic attention given to international dispute settlement has removed the field from the ambit, which was already fading since a couple of decades ago, of the perception of dispute settlement as only a practice and not of any legal scientific relevance. Scholarship has moved beyond analyzing specific courts or the outcome of decisions to tackle more overarching theoretical and conceptual debates on international dispute settlement, including socio-legal studies, critical studies, and empirical studies to name but a few, in order to analyze and understand the role and function of international dispute settlement and of specific mechanisms to settle disputes in international law and society. ${ }^{35} \mathrm{My}$ argument here has a form of circularity, I admit. But it is inevitable that the perception of dispute settlement as a legal discipline rather than only a practice goes hand in hand with the increase of interested scholarship.

All this has resulted in international dispute settlement moving from the perception that it is merely about 'doing law' to 'thinking about law'. ${ }^{36}$ International dispute settlement can no longer be considered a mere practical application of the law. The embedment of dispute settlement methods in international law, and the increase in practice, has resulted in a distance between the research in international dispute settlement and the practical realities of the field ${ }^{37}$ and the dissociation between theory and practice, which in this particular field is incremental towards

34 Obligations concerning Negotiations relating to Cessation of the Nuclear Arms Race and to Nuclear Disarmament (Marshall Islands v. United Kingdom), Preliminary objections, Judgment of 5 October 2016, [20I6] ICJ Rep. 833; Obligations concerning Negotiations relating to Cessation of the Nuclear Arms Race and to Nuclear Disarmament (Marshall Islands v. India), Jurisdiction and admissibility, Judgment of 5 October 2016, [2016] ICJ Rep. 255; and Obligations concerning Negotiations relating to Cessation of the Nuclear Arms Race and to Nuclear Disarmament (Marshall Islands v. Pakistan), Jurisdiction and admissibility, Judgment of 5 October 2016, [20I6] ICJ Rep. 552, available at www.icj-cij.org/en/list-of-all-cases. See in particular on the notion of 'justiciability' Marshall Islands v. United Kingdom, ibid., Dissenting Opinion of Vice-President Yusuf, paras. Io and I I.

35 T. Schultz, 'Editorial: The Evolution of International Arbitration as an Academic Field', (2015) 6 Journal of International Dispute Settlement 229-30.

36 T.Schultz, 'Editorial: Doing Law and Thinking about the Law',(2013) 4 Journal of International Dispute Settlement 2I7-I8.

37 See on this Schultz, supra note 23, at 279-86. 
achieving the status of legal discipline. The dissociation occurs not only at the level of the substance of what is researched, but also at the level of who is engaged in that research. It is still the case that some academic research on dispute settlement is also done by those who are at the same time practising in international dispute settlement. To a certain extent, this is inevitable since practitioners are often drawn from academia or vice versa - practitioners are taking up academic responsibilities because of their expertise. The importance however of the move of international dispute settlement from practice to discipline is that it has weakened the previously almost inherent link between practice and theory, paving the way to disinterested scholarship on the subject, which may perhaps never exist in a pure form. 